\title{
PENGARUH RASIO EFISIENSI, RISIKO OPERASI DAN LIKUIDITAS TERHADAP PROFITABILITAS PERUSAHAAN SUB SEKTOR TEKSTIL DAN GARMEN YANG TERDAFTAR DI BURSA EFEK INDONESIA PERIODE 2012-2018
}

\author{
Elisabet Mariani Buulolo ${ }^{1}$, Fony Yurika Zalmi ${ }^{1}$, Ayu Sihite ${ }^{1}$, Nadia Nurhaliza Daulay ${ }^{1}$, \\ D. Sakuntala ${ }^{1}$
}

E-mail: elisabetmarianibuulolo@gmail.com

${ }^{1}$ Program Studi Manajemen, Fakultas Ekonomi Universitas Prima Indonesia, Jl. Belanga, Medan, 20118, Indonesia

\begin{abstract}
This study aims to determine and to analyze the effect of the efficiency ratio, operation risk and liquidity against profitability in Textile and Garment Sub Sector Companies listed on the Indonesia Stock Exchange for the period 2012-2018. The research method used in this research is quantitative research methods, the type of research is quantitative descriptive. The population in this study were all companies in the Textile and Garment Sub-Sector as many as 17 companies with purposive sampling techniques obtained by 6 companies the data analysis method used in this study is the method of multiple linear regression and the classical assumption test. The results of this study indicate that simultaneously efficiency ratio, liquidity operational risk has a significant effect on profitability in the Textile and Garment sub-sector companies listed on the Indonesia Stock Exchange for the period 20122018 with the results of $F_{\text {count }}=4.586>F_{\text {table }}=2.85$. Partially, the efficiency and operational risk ratios have no significant effect on profitability while liquidity has a positive and significant effect on profitability with a $t_{\text {count }}=3.382>t_{\text {table }}=2.02619$ with a significant value of $0.002<0.05$.
\end{abstract}

Keywords: efficiency ratio; operational risk; liquidity; profitability

\section{PENDAHULUAN}

Perusahaan pada subsektor industri tekstil dan garmen adalah bagian dari sektor manufaktur terbesar ketiga di Indonesia. Tekstil dan garmen merupakan sektor yang memproduksi bahan baku serat, benang, kain pakaian jadi, aksesoris dan produk industri nonwoven. Tekstil dan garmen di Indonesia menjadi sektor yang paling banyak menyerap tenaga kerja dan juga mampu memberikan kontribusi besar terhadap pertumbuhan ekonomi, selain menciptakan lapangan kerja yang cukup besar industri ini juga mendorong peningkatan investasi baik di dalam negeri dan di luar negeri. Perubahan profitabilitas pada industri tekstil dan garmen sepanjang tahun 2012-2018 mengalami tren naik turun, di tahun 2015 industri ini menurun sebesar 4,79 persen akibat krisis ekonomi global dan efek perang dagang antara Amerika Serikat (AS) dan China, namun demikian industri tekstil dan garmen mampu bertahan dalam menghadapi krisis ekonomi global karena Indonesia dapat merespon dengan tepat dan sudah menunjukkan perbaikan disisi ekonomi nasional.

Perusahaan sub sektor tekstil dan garmen terus mengalami masalah yang sama dalam lima tahun terakhir, baik dari produksi maupun non produksi dimana dari 2,8 juta orang tenaga kerja memiliki produktivitas yang rendah, juga upah karyawan yang tiap tahun meningkat, selanjutnya harga gas dan juga biaya listrik yang tinggi dibanding negara lain mengakibatkan berkurangnya energi pendukung bagi industri tekstil dan garmen itu sendiri. Corporate Communication PT Asia Pasific Fibers Tbk menjelaskan bahwa dari awal tahun 2017 sektor Textil dan Produk Textil mengalami tekanan yang disebabkan oleh harga energi yang mahal sehingga produksi tidak efisien sehingga dengan demikian beban pokok 
penjualan ikut naik. Penjualan PT. Asia Pacific Fibers Tbk dalam laporan keuangan kuartal I2017 tercatat sebesar US\$ 100,2 juta atau memiliki kenaikan dari periode yang sama tahun sebelumnya sebesar US\$ 88,6 juta. Sehingga hal tersebut menyebabkan beban pokok penjualan ikut naik menjadi sebesar US\$ 93,7 juta atau lebih besar dari periode yang sama tahun sebelumnya sebesar US\$ 84,3 juta. Hal tersebut mengakibatkan terjadinya kerugian bersih sebesar US\$ 6,3 juta atau naik dari periode yang sama tahun sebelumnya sebesar US\$ 4,2 juta. Tahun 2017, Ade Sudrajat sebagai ketua Asosiasi Pertextilan Indonesia memberikan penjelasan bahwa industri textile di Indonesia dari segi ekspor maupun dari industri itu sendirimengalami penurun laba(www.Kontan.co.id).

Berdasarkan fenomena di atas dapat dinilai pergerakan pendapatan pada industri tekstil dan garmen mengalami perubahan setiap tahunnya hal tersebut mengakibatkan terjadinya kerugian bagi industri tekstil dan garmen. Hal ini dapat dipengaruhi oleh beberapa faktor yang ada di dalam perusahaan yaitu rasio efisiensi, risiko operasi dan likuiditas. Berdasarkan fenomena tersebut maka penelitian ini bertujuan untuk mengetahui pengaruh rasio efisiensi, risiko operasi dan likuiditas terhadap profitabilitas pada sub sektor industri tekstile dan garmen yang terdaftar di Bursa Efek Indonesia periode 2012-2018.

\section{TINJAUAN PUSTAKA}

Pengertian rasio efisiensi (perputaran persediaan). Rasio efisiensi (perputaran persediaan) merupakan rasio yang mampu menunjukkan berapa kali jumlah barang atau persediaan diganti dalam satu tahun periode akuntansi (Kasmir, 2012:180). Perputaran persediaan adalah perputaran dimana persediaan akan meningkat apabila permintaan konsumen meningkat (Haryono dan Lisiantara, 2018). Penghitungan rasio efisiensi menurut Kasmir (2012:180) disajikan berikut.

$$
\text { Inventory Turn Over }=\frac{\text { Penjualan }}{\text { Persediaan }}
$$

Pengertian risiko operasi (BOPO). Risiko operasi ini merupakan biaya yang bisa di pakai dalam memperoleh keuntungan yang kecil dibandingkan dengan keuntungan yang didapat oleh pengguna aktiva dimana semakin kecil risiko operasi atau BOPO maka semakin efisien biaya operasional yang dikeluarkan perusahaan yang bersangkutan (Capriani dan Dana, 2016). Menurut Sujarweni (2017:101), BOPO dapat dihitung berdasarkan indikator di bawah ini.

$$
\mathrm{BOPO}=\frac{\text { Biaya operasional }}{\text { Pendapatan operasional }}
$$

Pengertian likuiditas (QR). Menurut Hery (2015:181), rasio sangat lancar atau rasio cepat merupakan rasio yang digunakan untuk mengukur kemampuan perusahaan dalam memenuhi kewajiban jangka pendeknya yang segera jatuh tempo dengan menggunakan aset sangat lancar (kas + sekuritas jangka pendek + piutang), tidak termasuk persediaan barang dagang dan aset lancar lainnya. Santoso (2019) menjelaskan bahwa, jumlah aktiva lancar dimana persediaan tidak termasuk didalamnya dibagi dengan jumlah utang lancar. Pada umumnya perusahaan perusahaan menetapkan quick ratio $1: 1$ atau 100\%. Menurut Sujarweni (2017:61), quick ratio dapat dihitung dengan rumus sebagai berikut.

$$
\text { Quick Ratio }=\frac{\text { Aktiva lancar - persediaan }}{\text { Utang lancar }}
$$


Pengertian profitabilitas (ROA). Menurut Hery (2015:193), Return On Asset adalah jumlah pengembalian atas aset dalam menciptakan laba bersih, dengan kata lain rasio ini digunakan dalam mengukur besarnya jumlah laba bersih yang akan diperoleh setiap Rupiah dana yang tertanam dalam total aset. Return on Asset (ROA) dapat didefinisikan sebagai rasio yang menunjukkan seberapa banyak laba bersih yang bisa diperoleh dari seluruh kekayaan yang dimiliki perusahaan (Alhazami, 2019). ROA dihitung dengan indikator sebagai berikut (Hery, 2015:193).

$$
\text { ROA }=\frac{\text { Laba setelah pajak }}{\text { Total aktiva }}
$$

\section{Hipotesis penelitian}

Pengaruh rasio efisiensi (ITO) terhadap profitabilitas. Fahmi (2016:78) menjelaskan bahwa, apabila kepemilikan perputaran persediaan selalu dalam kondisi yang seimbang maka menunjukkan perusahaan tersebut baik. Artinya jika perputaran persediaan kecil maka akan terjadi penumpukan barang dalam gudang, namun sebaliknya apabila perputaran persediaan tinggi akan menyebabkan persediaan dalam gudang kecil. Jika sewaktu-waktu terjadi kehilangan bahan/barang dalam kejadian yang bersifat di luar perhitungan, maka ini bisa menyebabkan terganggunya aktivitas produksi perusahaan dan lebih jauh berpengaruh pada sisi penjualan serta perolehan keuntungan. Karamina dan Soekotjo (2018) menjelaskan bahwa perputaran persediaan digunakan untuk menunjukkan kemampuan perusahaan dalam mengelola persediaan, artinya berapa kali persediaan yang ada akan diubah menjadi penjualan. Kondisi yang mencerminkan tingkat perputaran persediaan yang semakin cepat adalah di pengaruhi oleh perputaran persediaan yang berpengaruh positif dan signifikan terhadap profitabilitas. Artinya perusahaan semakin efektif dalam menggunakan modal kerja yang tertanam dalam persediaan. Bila perusahaan memiliki persediaan yang tinggi maka rasio ini rendah, yang artinya banyak persediaan yang belum terjual. Hal ini akan mempengaruhi pengeluaran yang besar untuk biaya penyimpanan dan pemeliharaan, dengan rendahnya rasio ini akan berakibat pada terhambatnya arus kas.

H1 : Rasio efisiensi (ITO) berpengaruh terhadap profitabilitas

Pengaruh risiko operasi terhadap profitabilitas. Capriani dan Dana (2016) menjelaskan bahwa, berkurangnya laba sebelum pajak disebabkan oleh peningkatan biaya operasional yang pada akhirnnya akan mempengaruhi penurunan laba atau profitabilitas (ROA) perusahaan yang bersangkutan. Zulifiah dan Susilowibowo (2014) menjelaskan bahwa, beban yang begitu tinggi mempengaruhi profit yang rendah hal tersebut menunjukkan bahwa hubungan antara pendapatan dan pengeluaran sejalan.

H2 : Risiko operasi berpengaruh terhadap profitabilitas

Pengaruh likuiditas terhadap profitabilitas. Syamsudin (2011:41) menyatakan bahwa likuiditas tidak hanya berkenaan dengan keadaan keseluruhan perusahaan, tetapi juga berkaitan dengan kemampuannya mengubah aktiva lancar menjadi uang kas. Syamsuddin (2011:209) menjelaskan bahwa bilamana rasio likuiditas (quick ratio) meningkat maka profitabilitas (ROA) maupun risiko yang dihadapi akan menurun. Fahmi (2016:70) menjelaskan bahwa, quick ratio merupakan ukuran uji solvensi jangka pendek yang lebih teliti dari rasio lancar karena pembilangnya mengeliminasi persediaan berupa aktiva lancar yang sedikit tidak likuid dan kemungkinan menjadi sumber kerugian.

H3 : Likuiditas berpengaruh terhadap profitabilitas

Penelitian terdahulu. Purba (2017) menemukan bahwa pada sektor industri barang konsumsi yang terdaftar di Bursa Efek Indonesia dalam periode 2009-2013, Quick Ratio (QR) secara signifikan mempengaruhi Return On Assets (ROA). Susanto dan Kholis (2016) menemukan bahwa pada sektor perbankan yang terdaftar pada Bursa Efek Indonesia dalam 
periode 2007-2014, Capital Eduquacy Ratio (CAR), Net Profit Margin (NPM), dan Net Interest Margin (NIM) signifikan mempengaruhi Return On Assets (ROA) sedangkan Current Ratio (CR), Loan to Deposit Ratio (LDR), dan Biaya Operasional Pendapatan Operasional (BOPO) tidak signifikan. Hantono et al. (2019) menemukan bahwa pada sektor industri dasar dan kimia yang terdaftar pada Bursa Efek Indonesia dalam periode 2013-2017, perputaran persediaan secara parsial signifikan berpengaruh terhadap profitabilitas, sedangkan perputaran persediaan, current ratio, debt to equity ratio, dan total assets turn over tidak signifikan.

\section{METODE PENELITIAN}

Penelitian ini menggunakan pendekatan kuantitatif dengan analisis sebab akibat. Penelitian ini juga menggunakan metode deskriptif, guna mendeskripsikan hubungan antara satu variabel dengan variabel lain (Sujarweni, 2014:11). Populasi merupakan jumlah keseluruhan dimana didalamnya terdiri atas objek dan subjek dengan keistimewaan dan kualitas tertentu yang diterapkan untuk diteliti dan menyimpulkan hasil yang diperoleh. Populasi pada studi ini yaitu perusahaan sub sektor tekstil dan garmen yang terdaftar di Bursa Efek Indonesia periode 2012-2018 sebanyak 17 perusahaan. Sampel merupakan bagian dari sejumlah kualitas yang dimiliki oleh populasi yang dipakai untuk penelitian. Metode pengambilan sampel pada studi ini adalah sampling purposive. Sampling purposive merupakan teknik penentuan sampel dengan pertimbangan atau kriteria-kriteria tertentu (Sujarweni, 2014:65). Adapun kriteria pada penelitian ini yaitu:

1. Perusahaan sub sektor tekstil dan garmen yang terdaftar di Bursa Efek Indonesia periode 2012-2018.

2. Perusahaan sub sektor tekstil dan garmen yang mempublikasikan laporan keuangan secara berturut-turut selama periode 2012-2018.

3. Perusahaan sub sektor tekstil dan garmen yang mengalami laba selama periode 20122018.

Berdasarkan kriteria pemilihan sampel diatas, maka sampel penelitian menjadi 6 perusahaan sehingga menjadi 42 pengamatan. Teknik pengumpulan data pada penelitian ini menggunakan studi dokumentasi dan tinjauan pustaka. Tinjauan pustaka yaitu telaah buku rujukan atau buku teks yang berhubungan dengan judul penelitian ini. Dokumentasi yaitu perolehan data sekunder melalui https://www.idx.co.id berupa laporan keuangan perusahaan tekstil dan garmen di Bursa Efek Indonesia pada periode 2012-2018. Data sekunder merupakan data yang bisa didapatkan dari catatan, buku, majalah, berupa laporan keuangan publikasi perusahaan, laporan pemerintah, artikel buku-buku teori majalah (Sujarweni, 2014:74).

\section{HASIL ANALISIS DAN PEMBAHASAN}

\subsection{Hasil analisis}

Statistik deskriptif. Statistik deskriptif memperlihatkan gambaran tentang nilai minimum, nilai maksimum, total nilai rata-rata dan standar deviasi data yang dipakai pada penelitian ini. Statistik deskriptif penelitian dapat dilihat pada Tabel 1. 
Tabel 1. Tabel statistik deskriptif

\begin{tabular}{lccccc}
\hline & $\mathrm{N}$ & Minimum & Maximum & Mean & Std. Deviation \\
\hline Rasio Efisiensi & 42 & 0.0026 & 6.3417 & 3.398667 & 1.6347324 \\
Risiko operasi & 42 & -2.1464 & 3.0945 & -0.067560 & 1.2804121 \\
Likuiditas & 42 & 0.1963 & 5.0528 & 1.525945 & 1.3633645 \\
Profitabilitas & 42 & 0.0003 & 0.0774 & 0.019700 & 0.0244798 \\
Valid N (listwise) & 42 & & & &
\end{tabular}

Sumber: Data laporan keuangan perusahaan diolah, 2020

Tabel 1 menunjukkan bahwa total data yang dipakai pada penelitian ini berjumlah 42 data, yang diperoleh dari 6 sampel dikalikan dengan periode penelitian 7 tahun. Dapat diketahui bahwa nilai terendah rasio efisiensi dimiliki oleh STAR (Star Petrochem Tbk.) sebesar 0,0026 di tahun 2012 dan nilai tertinggi rasio efisiensi adalah 6,3417 yang terdapat pada perusahaan INDR (Indorama Synthetics Tbk.) pada tahun 2013, hasil diatas menunjukkan bahwa rasio efisiensi memiliki rata-rata 3,398667 dengan standar deviasi 1,6347324. Nilai minimum risiko operasi sebesar $-2,1464$ dimiliki oleh perusahaan RICY (Riky Globalindo Tbk.) pada tahun 2017 sedangkan nilai maksimum risiko operasi adalah 6,3417 pada perusahaan RICY ( Riky Globalindo Tbk.) di tahun 2016, dengan rata-rata risiko operasi sebesar -0,67560 dengan standar deviasi 1,2804121. Nilai minimum likuiditas sebesar 0,1963 yang dimiliki oleh perusahaan UNIT (Nusantara Inti Corpora Tbk.) di tahun 2013, sedangkan nilai maksimum likuiditas sebesar 5,0528 pada perusahaan SRIL (Sri Rezeki Tbk.) di tahun 2014 hasil tersebut menunjukkan rata-rata likuiditas sebesar 1,525945 dengan standar deviasi 1,3633645. Nilai terendah profitabilitas dimiliki oleh STAR (Star Petrochem Tbk.) sebesar 0,0003 di tahun 2018 dan nilai tertinggi profitabilitas adalah 0,0774 yang terdapat pada perusahaan INDR (Indorama Synthetics Tbk.) pada tahun 2018, hasil diatas menunjukkan bahwa profitabilitas memiliki rata-rata 0,019700 dengan standar deviasi sebesar 0,0244798 .

Uji normalitas. Uji normalitas bertujuan untuk menilai apakah residual error berdistribusi normal. Uji normalitas yang digunakan dalam mendeteksi distribusi residual error yaitu dengan analisis grafik dan statistik.

a. Grafik Histogram

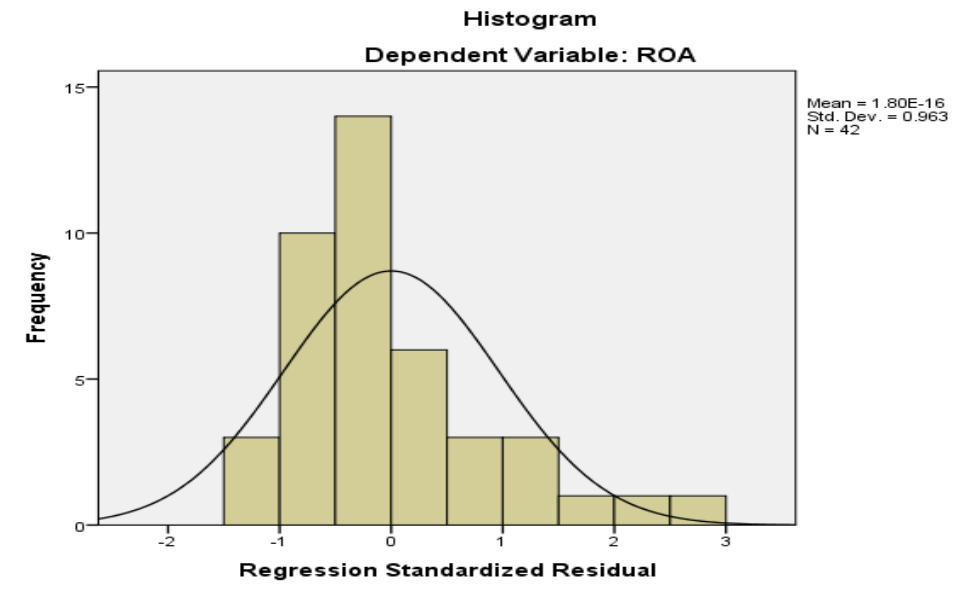

Gambar 1. Gambar Histogram

Gambar 1 menunjukkan bahwa residual error terdistribusi normal, hal ini dapat dilihat dari grafik histogram yang menunjukkan data simetris tidak melenceng kanan atau kiri.

b. Normal probabillty plot 


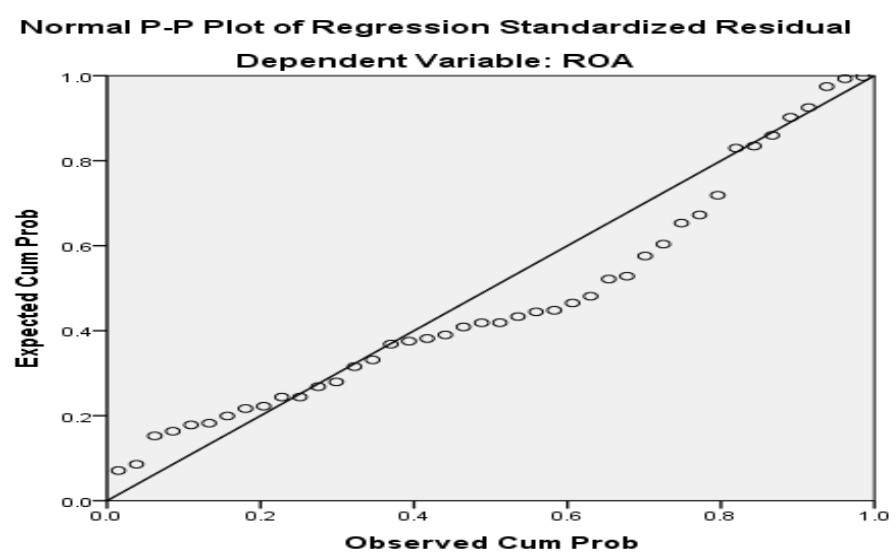

Gambar 2. Normal Probabilityplot

Gambar 2 menunjukkan bahwa residual error terdistribusi normal, dimana dapat dilihat bahwa titik-titik pada grafik normal probabillty plot tersebar diantara diagonal dan mengikuti sisi garis diagonal. Tabel 2 menunjukkan bahwa nilai signifikansi lebih besar dari 0,05 dimana nilai Asymp.sig (2-tailed) sebesar 0,218 (0,218>0,05) sehingga dapat disimpulkan bahwa model regresi memenuhi asumsi normalitas.

Tabel 2. Uji Kolmogrov Smirnov (K-S)

Unstandardized Residual

$\mathrm{N}$

Normal Parameters ${ }^{\mathrm{a}, \mathrm{b}}$ Mean $\quad 0 \mathrm{E}-7$

Std. Deviation

0.02097528

Most Extrime Differences

Absolutes

0.162

Positive

0.162

Negative

Kolmogrov-Smirnov Z

Asymp. Sig. (2-tailed)

a.Test distribution is normal

b.Calculated from data

Uji Multikolonieritas. Uji multikolinearitas memiliki tujuan agar dapat menilai apakah pada model regresi terdapat korelasi antara variabel independen. Suatu model regresi yang baik adalah tidak terjadi korelasi antar variabel bebas. Pengujian multikolinearitas dilakukan dengan melihat jumlah tolerance atau nilai VIF. Tabel 3 menunjukkan bahwa nilai tolerance untuk variabel rasio efisiensi sebesar 0,960 yang lebih besar dari 0,10 (0,960 > $0,10)$ dengan nilai VIF 1,042 kurang dari $10(1,042<10)$, risiko operasi nilai tolerance 0,965 lebih besar dari $0,10(0,965>0,10)$ dengan nilai VIF 1,036 kurang dari $10(1,036<10)$, likuiditas nilai tolerance sebesar 0,990 lebih besar dari $0,10(0,990>0,10)$ dan jumlah VIF sebesar 1,010 kurang dari $10(1,010<10)$ dapat disimpulkan nilai tersebut menunjukkan bahwa model regresi bebas dari multikolonieritas karena nilai tolerance lebih besar dari 0,10 dan VIF kurang dari 10. 
Tabel 3. Uji multikolonieritas

\begin{tabular}{lcc}
\hline \multicolumn{1}{c}{ Model } & \multicolumn{2}{c}{ Collinearity Statistics } \\
\hline (Constant) & & VIF \\
Rasio Efisiensi & 0.960 & \\
Risiko Operasi & 0.965 & 1.042 \\
Likiuditas & 0.990 & 1.036 \\
\hline
\end{tabular}

a. Dependent variable : Profitabilitas

Uji heteroskedastisitas. Uji heteroskedastisitas bertujuan untuk melihat apakah varians residual error dalam persamaan regresi adalah homogen. Pada Tabel 4, dapat dilihat bahwa masing-masing model menunjukkan nilai signifikansi lebih besar dari 0,05 sehingga bisa disimpulkan bahwa tidak terjadi gejala heteroskedastisitas.

Tabel 4. Heteroskedastisitas (uji Glejser)

\begin{tabular}{lccccc}
\hline \multirow{2}{*}{ Model } & \multicolumn{2}{c}{$\begin{array}{c}\text { Unstandardized } \\
\text { Coefficients }\end{array}$} & $\begin{array}{c}\text { Standardized } \\
\text { Coefficients }\end{array}$ & \multirow{2}{*}{ t } & sig \\
\cline { 2 - 5 } & $\mathbf{B}$ & Std.Error & Beta & & \\
\hline (Constant) & 0.015 & 0.005 & & 2.903 & 0.006 \\
Rasio Efisiensi & 0.002 & 0.001 & 0.271 & 1.746 & 0.089 \\
Risiko Operasi & -0.002 & 0.002 & -0.201 & -0.338 & 0.189 \\
Likuiditas & -0.004 & 0.002 & -0.272 & -1.786 & 0.082 \\
\hline
\end{tabular}

Uji autokorelasi. Pengujian autokorelasi bertujuan untuk dapat mengetahui apakah dalam suatu model regresi linear terdapat korelasi, untuk melihat terdapat atau tidaknya besaran autokorelasi dapat dilihat pada runs test dengan menggunakan besaran Asymp, Sig (2-tailed) pada output pengujian. Berdasarkan Tabel 5, nilai signifikan lebih besar dari 0,05 dimana nilai Asymp.sig (2-tailed) sebesar 0,876 (0,876 >0,05), sehingga dapat disimpulkan bahwa model penelitian ini terbebas dari autokorelasi.

\section{Tabel 5. Runs Test}

\begin{tabular}{lc}
\hline & Unstandardized Residual \\
\hline Test Value $^{\text {a }}$ & -0.00447 \\
Cases $<$ Test Value & 21 \\
Cases $>=$ Test Value & 21 \\
Total Cases & 42 \\
Number of Runs & 23 \\
Z & 0.156 \\
Asymp. Sig. (2-tailed) & 0.876 \\
\hline
\end{tabular}

a. Median

Analisis regresi linier beganda. Uji hipotesis yang dipakai pada penelitian ini adalah analisis regresi linier berganda. Tabel 6 menunjukkan bahwa persamaan regresi linier berganda adalah:

Profitabilitas $=-0,002+0,003 \mathrm{X} 1+0,002 \mathrm{X} 2+0,008 \mathrm{X} 3+\mathrm{e}$

Hasil interpretasi dari regresi linier diatas adalah:

1. Koefisien a (konstanta) $=-0,002$ yang artinya jika nilai variabel rasio efisiensi (X1), risiko operasi (X2) dan likuiditas (X3) dianggap stabil, sehingga nilai profitabilitas yaitu $-0,002$. 
2. $b_{1}$ (rasio efisiensi) $=0,003$ artinya hal ini menunjukkan bahwa setiap kenaikan rasio efisiensi 1 satuan nilai veriabel rasio efisiensi akan meningkatkan nilai variabel profitabilitas sebesar 0,003 satuan.

3. $b_{2}$ (risiko operasi) $=$ sebesar 0,002 artinya hal ini menunjukkan bahwa setiap kenaikan risiko operasi 1 satuan nilai variabel risiko operasi akan meningkatkan nilai variabel profitabilitas sebesar 0,002 satuan.

4. $\mathrm{b}_{3}$ (likuiditas) $=$ sebesar 0,008 artinya hal ini menunjukkan bahwa setiap kenaikan likuiditas 1 satuan nilai variabel likuiditas akan meningkatkan nilai variabel profitabilitas sebesar 0,008 satuan.

Tabel 6. Analisis regresi linier berganda

\begin{tabular}{lccc}
\hline \multirow{2}{*}{ Model } & \multicolumn{2}{c}{ Unstandardized Coefficients } & Standardized Coefficients \\
\cline { 2 - 4 } & B & Std. Error & Beta \\
\hline (Constant) & -0.002 & 0.009 & 0.174 \\
Rasio efisiensi & 0.003 & 0.002 & 0.082 \\
Risiko Operasi & 0.002 & 0.003 & 0.473 \\
Likuiditas & 0.008 & 0.003 & \\
\hline
\end{tabular}

Dependent Variable : Profitabilitas

Koefisien determinasi. Koefisien determinasi ditujukan guna menilai seberapa besar keefektifan model untuk menjelaskan variabel dependen apabila koefisien determinasi $\left(\mathrm{R}^{2}\right)$ semakin besar atau mendekati 1 , sehingga bisa dinyatakan bahwa seberapa besar variabel independen (X) dalam menjelaskan model variabel dependen (Y). Tabel 7 menunjukkan bahwa besarnya nilai Adjusted $\mathrm{R}^{2}$ adalah 0,208. Hal ini menunjukkan bahwa 20,8 \% variasi variabel profitabilitas (Y) dapat dijelaskan oleh variabel rasio efisiensi (X1), risiko operasi (X2), dan likuiditas (X3) sedangkan sisanya 79,2 \% merupakan variasi variabel lain yang tidak dijelaskan dalam penelitian ini.

\section{Tabel 7. Uji Koefisien Determinasi}

\begin{tabular}{ccccc}
\hline Model & R & R Square & Adjusted R Square & Std. Error of the Estimate \\
\hline 1 & $0.516^{\text {a }}$ & 0.266 & 0.208 & 0.0217875 \\
\hline
\end{tabular}

a. Predictors: (constant), Likuiditas, Risiko Operasi, Rasio Efisiensi

Pengujian hipotesis secara simultan. Uji F dipakai guna menilai apakah seluruh variabel bebas yang digunakan pada model regresi terdapat pengaruh secara bersama-sama terhadap variabel terikat (Ghozali, 2013:97). Tabel 8 menunjukkan bahwa secara bersamasama variabel independen berpengaruh serta signifikan terhadap dependen. Hasil uji statistik $F$ menghasilkan nilai $F_{\text {hitung }}$ sebesar 4,586. Sementara dengan perhitungan df1 (jumlah variabel-1) $=3$ dan df2 $(\mathrm{n}-\mathrm{k}-1)=38$, maka diperoleh nilai $\mathrm{F}_{\text {tabel }}$ adalah 2,85 dengan nilai signifikan dibawah 0,05 yaitu sebesar 0,008. Hasil dari statistik uji $\mathrm{F}$ menunjukkan hasil $F_{\text {hitung }}>F_{\text {tabel }}(4,586>2,85)$ dengan tingkat signifikan 0,05 . Hal tersebut menunjukkan bahwa rasio efisiensi, risiko operasi dan likuiditas secara simultan berpengaruh terhadap profitabilitas pada sub sector tekstil dan garmen yang terdaftar di Bursa Efek Indonesia periode 2012-2018. 
Tabel 8. ANOVA

\begin{tabular}{ccccccc}
\hline Model & & Sum of Squares & Df & Mean Square & F & Sig. \\
\hline \multirow{3}{*}{1} & Regression & 0.007 & 3 & 0.002 & 4.586 & $0.008^{\mathrm{b}}$ \\
& Residual & 0.018 & 38 & 0.000 & & \\
& Total & 0.025 & 41 & & & \\
\hline
\end{tabular}

a.Dependent Variable : Profitabilitas

b.Predictors : (constans), Likuiditas, Risiko Operasi, Rasio Efisiensi

Pengujian hipotesis secara parsial. Uji t-test dipakai untuk membuktikan sejauh mana pengaruh veriabel bebas terhadap variabel terikat. Tabel 9 menunjukkan bahwa nilai t tabel untuk profitabilitas 0,05 pada derajat bebas $n-k-1=42-4-1=37$ adalah sebesar 2,02619 dengan demikian hasil dari uji t dapat dijelaskan sebagai berikut :

a. Hasil hitung uji t secara parsial pada Rasio Efisiensi didapat hasil $t_{\text {hitung }}$ senilai 1,230 dan $t_{\text {tabel }}$ sebesar 2,02619 atau $t_{\text {hitung }}<t_{\text {tabel }}(1,230<2,02619)$ dengan nilai signifikan $0,226>0,05$ sehingga $\mathrm{H}_{\mathrm{o}}$ diterima $\mathrm{H}_{\mathrm{a}}$ ditolak artinya secara parsial rasio efisiensi tidak berpengaruh dan tidak signifikan terhadap profitabilitas pada tekstil dan garmen yang terdaftar di BEI periode 2012-2018.

b. Hasil hitung uji $\mathrm{t}$ secara parsial risiko operasi didapat nilai $\mathrm{t}_{\text {hitung }} 0,578$ dan $\mathrm{t}_{\text {tabel }}$ sebesar 2,02619 atau $t_{\text {hitung }}<\mathrm{t}_{\text {tabel }}(0,578<2,02619)$ dengan nilai signifikan $0,567>0,05$ maka $\mathrm{H}_{0}$ diterima $\mathrm{H}_{\mathrm{a}}$ ditolak artinya secara parsial risiko operasi tidak berpengaruh dan tidak signifikan terhadap profitabilitas pada sub sektor tekstil dan garmen yang terdaftar di Bursa Efek Indonesia periode 2012-2018.

c. Hasil hitung uji $t$ secara parsial pada likuiditas dihasilkan nilai $t_{\text {hitung }} 3,382$ dan $t_{\text {tabel }}$ sebesar 2,02619 atau $t_{\text {hitung }}>t_{\text {tabel }}(3,382>2,02619)$ dengan nilai signifikan $0,002<$ 0,05 maka $\mathrm{H}_{\mathrm{a}}$ diterima $\mathrm{H}_{0}$ ditolak artinya secara parsial likuiditas memiliki pengaruh yang positif dan signifikan terhadap profitabilitas pada perusahaan tekstil dan garmen yang terdaftar di Bursa Efek Indonesia periode 2012-2018.

Tabel 9. Uji t

\begin{tabular}{lccccc}
\hline Model & \multicolumn{2}{c}{$\begin{array}{c}\text { Unstandardized } \\
\text { Coefficients }\end{array}$} & $\begin{array}{c}\text { Standardized } \\
\text { Coefficients }\end{array}$ & t & Sig. \\
\hline & B & Std. Error & Beta & & \\
\hline (Constant) & -0.002 & 0.009 & & -0.236 & 0.814 \\
Rasio Efisiensi & 0.003 & 0.002 & 0.174 & 1.230 & 0.226 \\
Risiko Operasi & 0.002 & 0.003 & 0.082 & 0.578 & 0.567 \\
Likuiditas & 0.008 & 0.003 & 0.473 & 3.382 & 0.002 \\
\hline
\end{tabular}

Dependent Variable : Profitabilitas

\subsection{Pembahasan}

Pengaruh rasio efisiensi terhadap profitabilitas (ROA). Berdasarkan hasil pengujian hipotesis secara parsial maka dapat disimpulkan bahwa rasio efisiensi (perputaran persediaan) tidak memiliki pengaruh secara signifikan terhadap profitabilitas. Hal tersebut dikarenakan nilai thitung lebih kecil dari ttabel $(1,230<2,02619)$ dengan nilai signifikan 0,226 > 0,05 dengan demikian disimpulkan bahwa hasil penelitian ini H0 diterima dan Ha ditolak pada sub sektor tekstil dan garmen yang terdaftar di Bursa Efek Indonesia periode 2012-2018. Hasil penelitian ini berbeda dengan (Fahmi, 2016:78) dimana jika kepemilikan perputaran persediaan dalam keadaan seimbang maka menunjukkan kondisi perusahaan yang baik, artinya jika perputaran persediaan kecil maka akan terjadi penumpukan barang dalam gudang namun sebaliknya apabila perputaran persediaan tinggi akan menyebabkan persediaan dalam gudang akan kecil sehingga jika sewaktu-waktu terjadi kehilangan 
bahan/barang dalam kejadian yang bersifat diluar perhitungan, maka ini bisa menyebabkan terganggunya aktivitas produksi perusahaan dan lebih jauh berpengaruh pada sisi penjualan serta berpengaruh pada perolehan keuntungan. Hasil penelitian ini didukung oleh hasil penelitian terdahulu Hantono et al. (2019) dimana rasio efisiensi (perputaran persediaan) secara parsial tidak memiliki pengaruhterhadap variabel Return On Asset.

Pengaruh risiko operasi terhadap profitabilitas (ROA). Berdasarkan hasil pengujian hipotesis secara parsial maka dapat disimpulkan risiko operasi (BOPO) tidak berpengaruh signifikan terhadap profitabilitas. Hal tersebut dikarenakan nilai $t_{\text {hitung }}$ lebih kecil dari $\mathrm{t}_{\text {tabel }}(0,578<2,02619)$ dengan nilai signifikan $0,567>0,05$ dengan demikian bisa disimpulkan bahwa hasil penelitian ini berarti H0 diterima dan Ha ditolak pada sub sektor tekstil dan garmen yang terdaftar di Bursa Efek Indonesia periode 2012-2018. Hasil penelitian ini tidak sesuai dengan teori yang menyatakan berkurangnya laba sebelum pajak disebabkan oleh setiap kenaikan biaya operasional yang pada akhirnya akan menurunkan laba atau profitabilitas (ROA) perusahaan yang bersangkutan (Capriani dan Dana, 2016). Hasil penelitian ini didukung oleh hasil penelitian (Susanto dan Kholis, 2016) yang menyatakan BOPO secara parsial tidak berpengaruh secara signifikan terhadap variabel profitabilitas (Return On Asset).

Pengaruh likuiditas (quick ratio) terhadap profitablitas (ROA). Berdasarkan hasil pengujian hipotesis secara parsial maka dapat disimpulkan bahwa likuiditas (QR) berpengaruh positif dan signifikan terhadap profitabilitas. Hal tersebut dikarenakan nilai $t_{\text {hitung }}$ lebih besar dari $t_{\text {tabel }}(3,382>2,02619)$ dengan nilai signifikan $0,002<0.05$ dengan demikian bisa disimpulkan bahwa hasil penelitian ini berarti $\mathrm{HO}$ ditolak dan Ha diterima pada perusahaan tekstil dan garmen yang terdaftar di Bursa Efek Indonesia periode 2012-2018. Hasil penelitian ini sejalan dengan (Syamsuddin, 2011:41) dimana likuiditas tidak hanya berkenaan dengan keadaan keseluruhan keuangan perusahaan, tetapi juga berkaitan dengan kemampuan untuk mengubah aktiva lancar tertentu menjadi uang kas. Bilamana rasio likuiditas (QR) meningkat maka baik untuk profitabilitas (ROA) maupun risiko yang dihadapi akan menurun. Hasil penelitian ini didukung oleh hasil penelitian (Purba, 2017) yang menunjukkan bahwa quick ratio secara parsial berpengaruh signifikan terhadap variabel return on asset.

\section{KESIMPULAN DAN SARAN}

\subsection{Kesimpulan}

Berdasarkan hasil penelitian ini adalah mengenai hasil temuan dan kesesuaian teori, pendapat, maupun maupun penelitian terdahulu yang telah ditemukan sebelumnya. Berikut hasil temuan dalam penelitian adalah :

1. Rasio efisiensi (perputaran persediaan) secara parsial tidak signifikan terhadap profitabilitas (ROA) pada sub sektor tekstil dan garmen yang terdaftar di Bursa Efek Indonesia periode 2012-2018, dimana nilai $t_{\text {hitung }}<t_{\text {tabel }}(1,230<2,02619)$ dengan nilai signifikan $0,226>0,05$.

2. Risiko operasi ( BOPO) secara parsial tidak signifikan terhadap profitabilitas (ROA) pada sub sektor tekstil dan garmen yang terdaftar di Bursa Efek Indonesia periode 2012-2018, dengan nilai $t_{\text {hitung }}<t_{\text {tabel }}(0,578<2,02619)$ dengan nilai signifikan $0,567>0,05$.

3. Likuiditas (quick ratio) secara parsial berpengaruh positif dan signifikan terhadap profitabilitas (ROA) pada perusahaan tekstil dan garmen yang terdaftar di Bursa Efek Indonesia periode 2012-2018, dengan nilai $t_{\text {hitung }}>t_{\text {tabel }}(3,382>2,02619)$.

\subsection{Saran}

Bagi investor, tidak perlu ragu mengambil keputusan untuk berinvestasi karena modal berputar dengan baik maka laba yang dihasilkan juga meningkat sehingga investor tidak perlu ragu untuk menanamkan sahamnya di perusahaan tekstil dan garmen. Bagi peneliti 
selanjutnya, keterbatasan dalam penelitian ini hendaknya lebih disempurnakan misalnya dengan menambahkan jumlah variabel bebas penelitian atau periode pengamatan pada sub sektor yang sama yaitu perusahaan tekstil dan garmen.

\section{DAFTAR PUSTAKA}

Alhazami. L. (2019). Determinasi ratio profitabilitas pada return saham studi kasus perusahaan pertambangan di Bursa Efek Indonesia (BEI) tahun 2013-2017. Jurnal Mitra Manajemen, 3(10), 946-959. http://www.ejurnalmitramanajemen.com/index.php/jmm/article/view/286

Capriani, N. W. W., \& Dana, I. M. (2016). Pengaruh risiko kredit, risiko operasional dan risiko likuiditas terhadap profitabilitas BPR di Kota Denpansar. E Jurnal Manajemen, 5(3), 1486-1512. https://ojs.unud.ac.id/index.php/Manajemen/article/view/16316

Fahmi, I. (2016). Pengantar manajemen keuangan: Teori dan soal jawab. Bandung: Alfabeta.

Ghozali, I. (2013). Aplikasi analisis multivariate dengan Program IBM SPSS 21. Semarang: Badan Penerbit Universitas Diponegoro

Hantono, Guci, S. T., Manalu, E. M. B., Hondro, N. A., Manihuruk, C. C., Perangin-Angin, M. Br., \& Sinaga, D. C. (2019). Pengaruh perputaran kas kerja dan perputaran piutang, perputaran persediaan, current ratio. dan debt to equity ratio, total turn over terhadap profitabilitas periode 2013-2017 (Studi kasus pada Sektor Industri Dasar dan Kimia). Riset dan Jurnal Akuntansi, 3(1), 116-127. https://doi.org/10.33395/owner.v3i1.110.

Haryono. V. E., \& Lisiantara, G. A. (2018). Perputaran kas, perputaran persediaan, dan perputaran piutang dengan ukuran perusahaan sebagai variabel kontrol terhadap profitabilitas (Studi pada perusahaan manufaktur sektor industri barang konsumsi yang terdaftar di Bursa Efek Indonesia periode 2014-2017). Dinamika Akuntansi Keuangan dan Perbankan, 7(1), 45-56. https://www.unisbank.ac.id/ojs/index.php/fe9/article/view/7445

Hery. (2015). Analisis laporan keuangan: Pendekatan rasio keuangan. Yogyakarta: CAPS (Center For Academic Publishing Service).

Kasmir. (2012). Analisis laporan keuangan. Jakarta: PT. Raja Grafindo Persada.

Karamina, R. A., \& Soekotjo, H. (2018). Pengaruh perputaran modal kerja, perputaran kas, perputaran pesediaan dan perputaran piutang terhadap profitabilitas. Jurnal Ilmu Dan Riset Manajemen, 7(3), 1-20. http://jurnalmahasiswa.stiesia.ac.id/index.php/jirm/article/view/431

Purba,R. (2017). Pengaruh Quick Ratio (QR) terhadap Return On Asset (ROA) pada perusahaan sektor industri barang konsumsi periode 2009-2013. Jurnal Ilmiah Maksitek, $2(2)$, http://sciencemakarioz.org/jurnal/index.php/maksitek/article/viewFile/33/37

Santoso, M. H. B. (2019). Analisis rasio keuangan untuk menilai efesiensi modal kerja (Studi kasus pada PT. Adira Finance tahun 2013-2018). Jurnal Sains Manajemen dan Bisnis Indonesia, $9(1)$, 68-73. http://jurnal.unmuhjember.ac.id/index.php/SMBI/article/view/2374

Sujarweni, V. W. (2014). Metode penelitian. Yogyakarta: Pustaka Baru Press.

Sujarweni, V. W. (2017). Analisis laporan keuangan: Teori, aplikasi \& hasil penelitian. Yogyakarta: Pustaka Baru Press.

Susanto, H., \& Kholis, N. (2016). Analisis rasio keuangan terhadap profitabilitas pada perbankan Indonesia. Jurnal Ebbank, 7(1), 11-22. http://www.ebbank.stiebbank.ac.id/index.php/EBBANK/article/view/83 
Syamsuddin, L. (2011). Manajemen keuangan perusahaan. Jakarta: Rajawali Pers.

Zulifiah, F., \& Susilowibowo, J. (2014). Pengaruh inflasi, BI Rate, Capital Adequacy Ratio (CAR), Non Performing Finance (NPF), Biaya Operasional, dan Pendapatan Operasional (BOPO) terhadap profitabilitas pada perusahaan Bank Umum Syariah periode 2008-2012. Jurnal Ilmu Manajemen, 2(3), 759-770. https://jurnalmahasiswa.unesa.ac.id/index.php/jim/article/download/10168/9936 